\section{Sodium Distribution in Salt-stressed Citrus Rootstock Seedlings}

\author{
Pedro Gonzalez, James P. Syvertsen, and Ed Etxeberria ${ }^{1}$ \\ University of Florida, IFAS, Horticultural Sciences Department, \\ Citrus Research and Education Center, 700 Experiment Station Road, \\ Lake Alfred, FL 33850
}

Additional index words. $\mathrm{Na}^{+}$exclusion, $\mathrm{Na}^{+}$transport, salinity tolerance, salt stress, vacuole sequestration

\begin{abstract}
Although citrus trees are considered relatively salt-sensitive, there are consistent differences in $\mathrm{Na}^{+}$and $\mathrm{Cl}^{-}$tolerance among different citrus rootstocks. We grew uniform seedlings of rough lemon (RL) and the more $\mathrm{Na}^{+}$-tolerant Swingle citrumelo (SC) with and without $50 \mathrm{~mm} \mathrm{NaCl}$ for $\mathbf{4 2}$ days. Salinity reduced leaf chlorophyll and plant transpiration rate $\left(E_{p}\right)$ more in $R L$ than $S C$. Confocal laser scanning analyses using the $\mathrm{Na}^{+}$-specific cellpermeant fluorescent probe CoroNa-Red revealed a higher capacity for $\mathrm{Na}^{+}$sequestration in root tissue vacuoles of $S C$ than in RL roots and that cell walls within the stele acted as $\mathrm{Na}^{+}$traps. In leaves, however, $\mathrm{RL}$ had significantly higher $\mathrm{Na}^{+}$-dependent fluorescence than SC. Thus, the sequestration of $\mathrm{Na}^{+}$in root tissue vacuoles and its immobilization by cell walls were key contributing mechanisms enabling SC leaves to maintain lower levels of $\mathrm{Na}^{+}$than RL leaves. Examination of intracellular distribution of CoroNa-Green fluorescence in SC root protoplasts verified a vacuolar localization for $\mathrm{Na}^{+}$in addition to the presence of a 2- to $6-\mu \mathrm{m}$ unidentified endosomal compartment containing significantly higher $\mathrm{Na}^{+}$concentrations.
\end{abstract}

Although citrus trees are considered relatively salt-sensitive, there are inherent differences in $\mathrm{Na}^{+}$and $\mathrm{Cl}^{-}$tolerance among the many commercial citrus rootstocks (Castle et al., 2006; Maas, 1993). Salinity tolerance of citrus rootstocks is gauged by satisfactory tree growth and fruit yield under saline conditions (Castle et al., 1993) along with the amount of $\mathrm{Cl}^{-}$and/or $\mathrm{Na}^{+}$accumulated in foliage (Levy and Syvertsen, 2004; Maas, 1993). There are often conflicting interpretations of the relative levels of rootstock tolerance to salinity depending on variations in salinity treatments, treatment duration, scion type, growth substrate, and which type of physiological responses were measured (Levy and Syvertsen, 2004; Zekri and Parsons, 1992).

Salt tolerance represents the natural ability to cope with absorbed salt ions usually involving the chelation, exclusion, or sequestration of toxic concentrations of salts away from the photosynthetic machinery in leaves (Munns and Tester, 2008). Because citrus trees are usually grafted onto rootstocks, these trees represent an opportunity to study their ability to restrict the transfer of salt ions to the shoot when used as rootstocks. Rootstock characteristics tend to be consistent even when grown as seedlings in a greenhouse (Syvertsen et al., 2010). Citrus and other fruit trees are somewhat unique in that $\mathrm{Cl}^{-}$ions are considered to be more toxic than $\mathrm{Na}^{+}$ions (Levy and Syvertsen, 2004). Thus,

Received for publication 23 May 2012. Accepted for publication 6 Aug. 2012.

${ }^{1}$ To whom reprint requests should be addressed; e-mail eetxeber@ufl.edu. salt tolerance in citrus is usually based on $\mathrm{Cl}^{-}$ toxicity (Maas, 1993), but $\mathrm{Cl}^{-}$toxicity is seldom studied in the absence of $\mathrm{Na}^{+}$. Alorgan level are well described among citrus rootstocks with varying salt tolerances (Garcia-Sanchez and Syvertsen, 2006; Zekri and Parsons, 1992), the fundamental nature of the exclusion, sequestration, and/or compartmentation at the tissue and cell levels remains unresolved. Our preliminary dye fluorescence studies on $\mathrm{Na}+$ and $\mathrm{Cl}^{-}$distribution in citrus tissues revealed that $\mathrm{Na}^{+}$dyes are more effective than $\mathrm{Cl}^{-}$dyes in their fluorescence intensity and stability properties. Thus, as a first step toward understanding salt tolerance and salt ion distribution in citrus tissues, we studied $\mathrm{Na}^{+}$distribution in root and leaf tissues of seedlings of citrus rootstocks with contrasting tolerances to $\mathrm{Na}^{+}$ ions. Despite the critical importance of active $\mathrm{Na}^{+}$efflux systems for salinity tolerance in many plant species (see review by Munns and Tester, 2008), such systems have not been characterized in salt-sensitive citrus trees.

$\mathrm{Na}^{+}$tolerance can be achieved by reducing $\mathrm{Na}^{+}$uptake by the roots, sequestration within the root tissues, decrease loading to the xylem, or by an enhanced capacity of intracellular compartmentation of $\mathrm{Na}^{+}$in leaf cells (Hasegawa et al., 2000; Tester and Davenport, 2003). In addition, large amounts of ions could be excluded from the metabolic milieu by sequestration in the apoplast as reported for metal ions (Mari and Lebrun, 2006). In both roots and shoots, metabolic activities that impart salt tolerance require coordination between cell and tissue types mostly mediated by membrane-bound carriers though the allocations of $\mathrm{Na}+$ and $\mathrm{Cl}^{-}$at the and transporters (Cuin et al., 2011). Important mechanisms that contribute to $\mathrm{Na}^{+}$tolerance are the membrane-localized $\mathrm{Na}+$ transporters at the tonoplast and the plasmalemma (Tester and Davenport, 2003). Tonoplast-bound $\mathrm{Na}^{+} /$ $\mathrm{H}^{+}$antiporters mediate the removal of $\mathrm{Na}+$ into the vacuole. Overexpression of $\mathrm{Na}^{+} / \mathrm{H}^{+}$ antiporters in Arabidopsis (Shi et al., 2003), Brassica (Zhang et al., 2001), and tomato (Zhang and Blumwald, 2001) has resulted in significant improvements in salt tolerance. Using a variety of fluorescent dyes, Hamaji et al. (2009) demonstrated the almost exclusive localization of $\mathrm{Na}^{+}$in the vacuolar space of root cortical cells and in root suspension cultured cells of Arabidopsis.

Removing excess $\mathrm{Na}^{+}$from the cytosol can also be accomplished by plasmalemmabound $\mathrm{Na}^{+}$efflux transporters that extrude $\mathrm{Na}^{+}$to the apoplastic space (Shi et al., 2002). The use of the apoplast as a depository of surplus or toxic ions has been demonstrated for metal ions such as nickel in roots of Leptoplax (Redjala et al., 2010). The ability of a salt-tolerant wheat cultivar, Kharchia 65 (Cuin et al., 2011), to extrude $\mathrm{Na}^{+}$from the roots may contribute to its salinity tolerance. However, this strategy may be only delaying the transfer of toxic levels of $\mathrm{Na}^{+}$from roots to shoots.

At the whole plant level, different citrus rootstock species can differ in their allocations of $\mathrm{Na}^{+}$between roots and shoots (GarciaSanchez and Syvertsen, 2006, 2009). Although the common citrus rootstock rough lemon (RL) (Citrus jambhiri Lush.) and Swingle citrumelo (SC) [C. paradisi Macf. $\times$ Poncirus trifoliata (L.) Raf] are both considered salt-sensitive based on $\mathrm{Cl}^{-}$toxicity, SC (and other P.t. hybrid rootstocks) has the ability to limit $\mathrm{Na}^{+}$accumulation in leaves compared with RL (Levy and Syvertsen, 2004). The mechanism of how such a difference in $\mathrm{Na}^{+}$distribution occurs in trees grafted on these contrasting rootstocks could be related to differences in $\mathrm{Na}^{+}$sequestration in their root tissues. Thus, based on molecular analyses in Arabidopsis (Shi et al., 2003; Zhu, 2000) and on determinations of intracellular $\mathrm{Na}^{+}$distribution with Sodium-Green (Hamaji et al., 2009), we hypothesized a higher $\mathrm{Na}^{+}$sequestration in the root vacuoles of the relatively $\mathrm{Na}^{+}$-tolerant $\mathrm{SC}$ than in RL roots. In this report, tissue $\mathrm{Na}^{+}$distribution was analyzed on a tissue dry weight basis and microscopically visualized using CoroNa-Red and CoroNa-Green dyes by laser scanning confocal microscopy. We also wanted to determine if fluorescence-based visualization of cellular $\mathrm{Na}^{+}$distribution corresponded to tissue $\mathrm{Na}^{+}$concentration expressed on a dry weight basis.

\section{Materials and Methods}

Plant material. Uniform 3-month-old seedlings of the salt-sensitive rootstock RL (Citrus jambhiri Lush) and the relatively salt-tolerant $\mathrm{SC}[C$. paradisi Macf. $\times$ C. trifoliata $(\mathrm{L}$.) Raf] were purchased from a commercial nursery and transplanted into 0.5 -L plastic pots 
filled with a peat, perlite, vermiculite (3:1:1) soilless media. Seedlings were grown in a greenhouse under natural photoperiods during the late summer when maximum photosynthetically active radiation at the plant level was $\approx 1200 \mu \mathrm{mol} \cdot \mathrm{m}^{-2} \cdot \mathrm{s}^{-1}$ (LI-170; LICOR, Lincoln, NE). The average day/night temperature was $36 / 21{ }^{\circ} \mathrm{C}$ and relative humidity varied diurnally from $40 \%$ to $100 \%$. Plants were irrigated every other day with a dilute solution of a complete fertilizer $(8 \mathrm{~N}-0.7 \mathrm{P}-$ $6.6 \mathrm{~K})$ at $100 \mathrm{mg} \cdot \mathrm{L}^{-1}$ nitrogen $(\mathrm{N})$ plus $6 \%$ iron chelate in a sufficient volume to leach from the bottom of all pots. Plants received

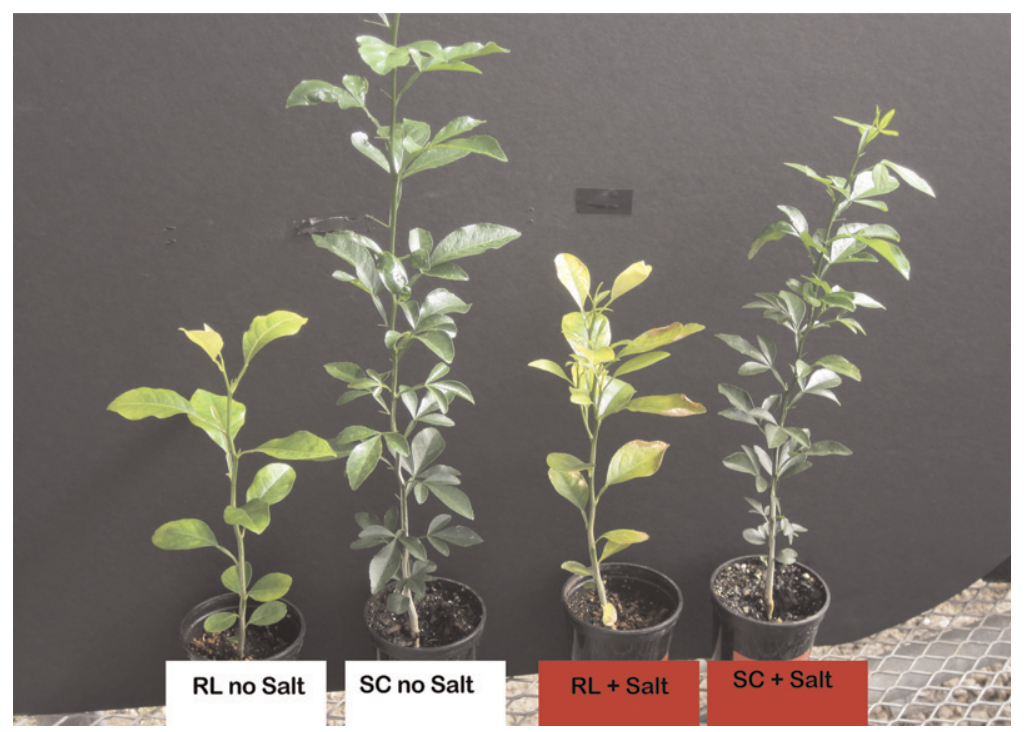

Fig. 1. Visual appearance of rough lemon (RL) and Swingle citrumelo (SC) plants after $42 \mathrm{~d}$ with and without salt treatment.
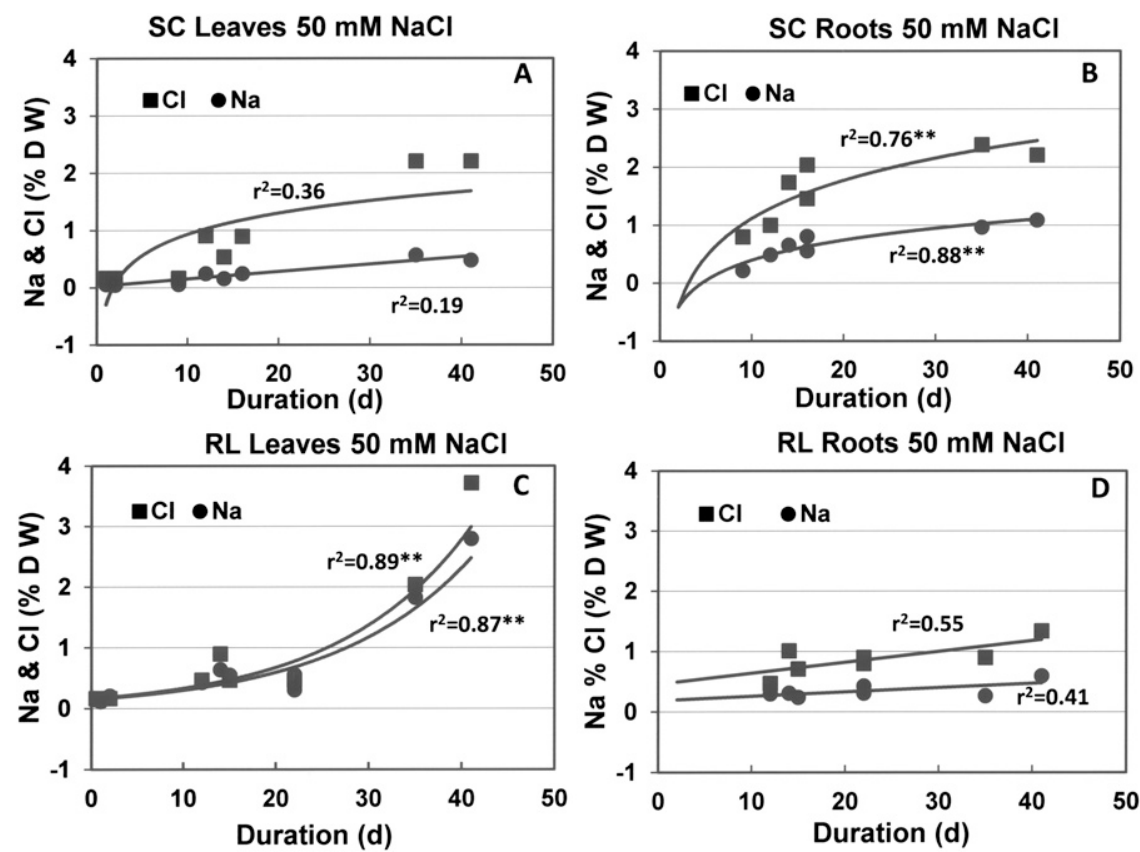

Fig. 2. Accumulation of $\mathrm{Na}^{+}$and $\mathrm{Cl}^{-}$in leaves and roots of Swingle citrumelo (SC) and rough lemon (RL) citrus rootstocks irrigated with $50 \mathrm{~mm} \mathrm{NaCl}$ during $42 \mathrm{~d}$. **Significant at $P<0.01$. Each symbol represents one plant.
All leaf measurements used fully expanded mature leaves from the midstem area on each seedling. As an index of leaf chlorophyll, leaf greenness was estimated using a SPAD meter (SPAD-502; Minolta Corp., Ramsey, NJ).

Near the end of the experiment, whole plant transpiration $\left(\mathrm{E}_{\mathrm{p}}\right)$ was measured gravimetrically by daily weight loss from three replicate pots sealed in a plastic bag at the base of the stem, divided by the total leaf area at harvest, and expressed in units of $\mathrm{g} \cdot \mathrm{m}^{-2} \cdot \mathrm{h}^{-1}$. Harvested plants were separated into leaves, stems, and roots, briefly rinsed in deionized water, and oven-dried at $60{ }^{\circ} \mathrm{C}$ for at least $48 \mathrm{~h}$. Dried mature leaves and fibrous roots were ground to a powder and leaf $\mathrm{N}$, $\mathrm{Na}^{+}$, and $\mathrm{Cl}^{-}$concentrations were determined in a commercial laboratory (Waters Agricultural Laboratory, Camilla, GA) and expressed as a percentage dry weight.

Confocal microscopy. At periodic harvest times, water rinsed roots of RL and SC were excised $0.5 \mathrm{~cm}$ from the root tip and leaves were separated at the base of the petiole. Root tissue was sliced into 1- to 2-mm segments and incubated in an incubation solution containing $20 \mathrm{~mm}$ Buffer MOPS pH 7.0, 0.5 mM $\mathrm{CaSO}_{4}$, and $200 \mathrm{~mm}$ sorbitol (incubation media) to recover from effects of excision and sudden changes in osmolarity and salt concentration (Davenport and Tester, 2000). Sampled leaves were sliced in segments of approximately the same size as roots at the time of sampling.

For $\mathrm{Na}^{+}$compartmentation analysis by fluorescent laser scanning confocal microscopy (Leica TCS SL; Leica, Heidelberg, Germany), leaf and root segments from 0 and $50 \mathrm{~mm}$ treated RL and SC citrus plants were incubated in $10 \mu \mathrm{M}$ of cell permeant CoroNaRed fluorescent sodium indicator (Molecular Probes, C-24431; Invitrogen, Eugene, OR) in the incubation media above for $12 \mathrm{~h}$. Tissue segments were washed three times to remove any excess fluorescent dye using the incubation solution without the CoroNa-Red. The microscope setting for detecting CoroNa-Red was $\lambda$ exc $=543 \mathrm{~nm}$ and $\lambda$ em over the 565 - to $600-\mathrm{nm}$ spectral band. A series of confocal optical XY images through the thickness of the samples (total scanning volume was $\approx 150 \mu \mathrm{m}$ with a slice thickness of $3 \mu \mathrm{m}$ ) were acquired in XYZ scanning mode using the Leica TCS SL software package. Comparison of different levels of fluorescence between cells was carried out by visualizing cells with the identical imaging settings of the confocal microscope (i.e., laser intensity, pinhole diameter, and settings of the imaging detectors)

Protoplast isolation and observation. Protoplasts from SC roots were isolated by incubating root segments overnight in a cell wall hydrolytic solution containing $50 \mathrm{~mm}$ BTP/MES buffer (pH 5.6), 800 mm sorbitol, 2\% Cellulase Onozuka RS (from Trichoderma viride; SERVA Electrophoresis $\mathrm{GmbH}$, Germany), 1.25\% Macerozyme R-10 from Rhizopus sp. (SERVA Electrophoresis $\mathrm{GmbH}$, Germany), $0.5 \%$ pectinase from Aspergillus 
niger (CALBIOCHEM, Germany), 0.1\% rum albumin, and $1 \mathrm{mM} \mathrm{CaCl}_{2}$. After $12 \mathrm{~h}$ of incubation, the protoplasts were washed with the hydrolytic solution without the enzymes and then incubated with $10 \mu \mathrm{M}$ cell-permeant CoroNa-Green Sodium Indicator (Molecular Probes, C-36676; Invitrogen) for an additional $8 \mathrm{~h}$. Fluorescent laser scanning images with CoroNa-Green were obtained using $\lambda$ exc $=$ $488 \mathrm{~nm}$ and $\lambda$ em over the $510-$ to $540-\mathrm{nm}$ spectral band. Some of the root protoplasts were incubated with $5 \mu \mathrm{M}$ Hoechst 33342 (Molecular Probes, H3570; Invitrogen) together with CoroNa-Green and observed under fluorescent microscopy with corresponding green and blue fluorescence filters. Photographs were taken with a Canon digital camera adapted to the microscope. polyvinylpyrrolidone- $40,0.05 \%$ bovine se-

\section{Results}

Plant growth and ion concentration. All non-salinized seedlings appeared healthy and showed no signs of impaired growth. Salinized RL seedlings appeared chlorotic and had visible tip burn on most leaves after $40 \mathrm{~d}$ of salt treatment (Fig. 1). Salinized SC plants grew less than control plants but did not display any visible phytotoxic symptoms. At the end of the experimental period, root $\mathrm{Na}^{+}$ concentrations in $\mathrm{SC}$ exceeded leaf $\mathrm{Na}^{+}$concentrations but root and leaf $\mathrm{Cl}^{-}$concentrations were similar (Fig. 2A-B). In SC, leaf $\mathrm{Cl}^{-}$concentrations far exceeded levels considered to be toxic in bearing trees $(0.7 \%$; Obreza and Morgan, 2008). In RL, both $\mathrm{Na}^{+}$and $\mathrm{Cl}^{-}$concentrations in salinized leaves exceeded concentration in roots, and concentrations

Table 1. Effects of rough lemon (RL) and Swingle citrumelo (SC) rootstock and $42 \mathrm{~d}$ of salt treatment $(0$ or $50 \mathrm{~mm} \mathrm{NaCl})$ on mean $(n=3)$ plant transpiration $\left(\mathrm{E}_{\mathrm{p}}\right)$, chlorophyll (SPAD) index, leaf nitrogen, sodium and chlorine concentrations of 6-month-old seedlings. ${ }^{2}$

\begin{tabular}{|c|c|c|c|c|c|c|}
\hline & & $E_{p}$ & & Leaf nitrogen & Chlorine & Sodium \\
\hline Rootstock & Salt & $\left(\mathrm{g} \cdot \mathrm{m}^{-2} \cdot \mathrm{h}^{-1}\right)$ & Chlorophyll index & \multicolumn{3}{|c|}{ (\% dry wt) } \\
\hline$\overline{\mathrm{RL}}$ & $0 \mathrm{~mm}$ & $65 \mathrm{a}$ & $49 \mathrm{~b}$ & $2.3 \mathrm{c}$ & $0.2 \mathrm{~b}$ & $0.2 \mathrm{bc}$ \\
\hline RL & $50 \mathrm{~mm}$ & $25 \mathrm{~b}$ & $23 \mathrm{c}$ & $2.7 \mathrm{~b}$ & $2.9 \mathrm{a}$ & $2.3 \mathrm{a}$ \\
\hline $\mathrm{SC}$ & $0 \mathrm{~mm}$ & $59 \mathrm{a}$ & $62 \mathrm{a}$ & $3.1 \mathrm{a}$ & $0.2 \mathrm{~b}$ & $0.1 \mathrm{c}$ \\
\hline$\underline{\mathrm{SC}}$ & $50 \mathrm{~mm}$ & $38 \mathrm{~b}$ & $50 \mathrm{~b}$ & $3.1 \mathrm{a}$ & $2.2 \mathrm{a}$ & $0.5 \mathrm{~b}$ \\
\hline
\end{tabular}

${ }^{\mathrm{z}}$ Values within a column followed by different letters differ significantly at $P<0.05$.

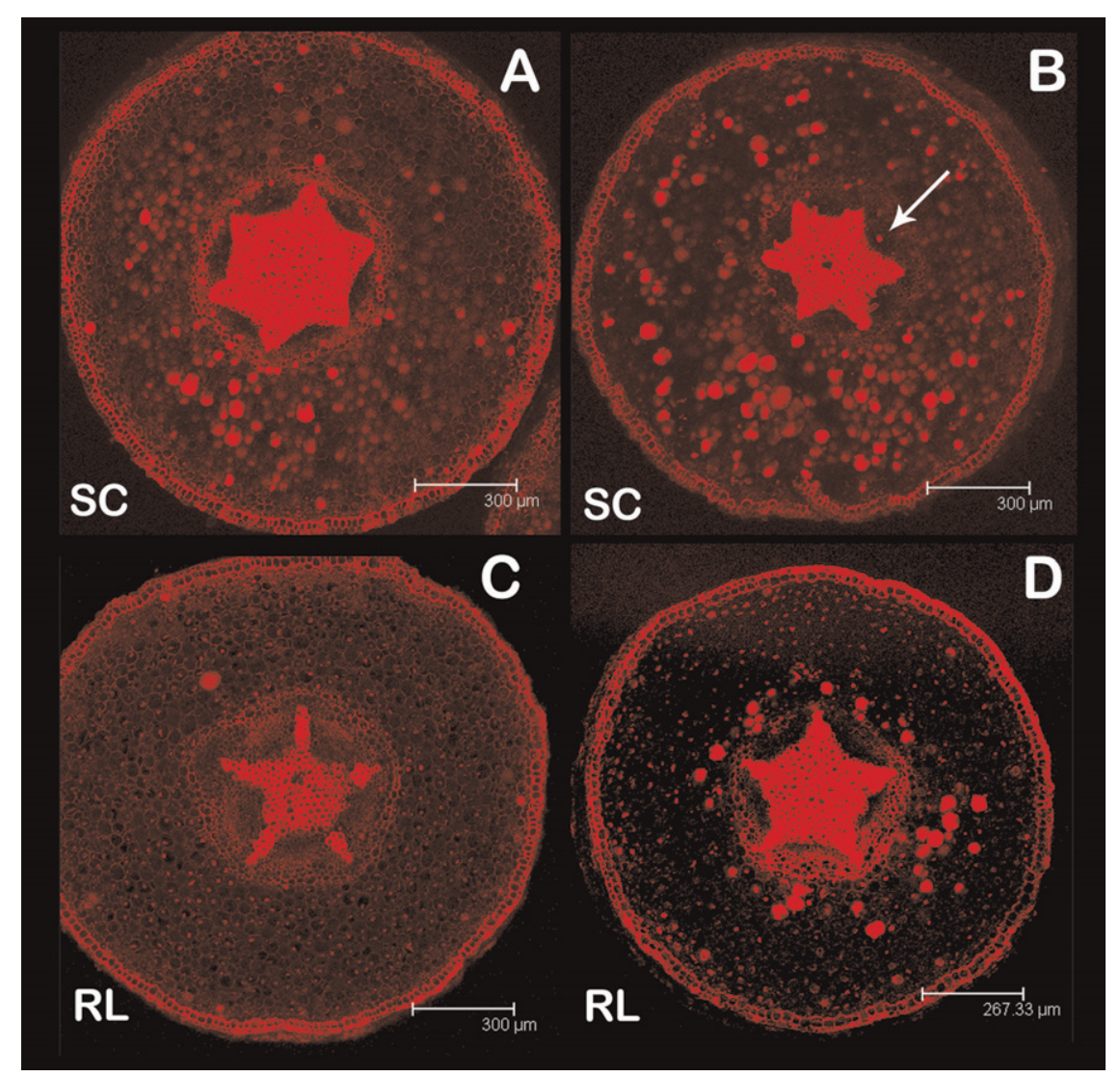

Fig. 3. Laser scanning confocal images of roots from Swingle citrumelo (SC) and rough lemon (RL) without $\mathrm{NaCl}$ treatment (A, C) and after $50 \mathrm{~mm} \mathrm{NaCl}$ treatment (B, D) for $42 \mathrm{~d}$. Root segments were cut perpendicularly and incubated in CoroNa-Red added before visualization. Arrow in $\mathbf{B}$ denotes $\mathrm{Na}^{+}$accumulating cell in the pericycle. of both ions in salinized leaves exceeded toxic levels after approximately Day 25 (Fig. $2 \mathrm{C}-\mathrm{D})$.

Leaf $\mathrm{Na}^{+}$in salinized RL exceeded concentrations in salinized SC leaves (Table 1); leaf $\mathrm{Cl}^{-}$levels in $\mathrm{RL}$ were numerically higher but not significantly different from SC leaves. Although all plants were well fertilized, the largest non-salinized RL seedlings developed low leaf $\mathrm{N}$ below optimum (Obreza and Morgan, 2008) but all other plants had leaf N concentrations at or above optimum values of $2.7 \%$. Salinity reduced $E_{p}$ and leaf chlorophyll in both rootstock types but $E_{p}$ did not differ between rootstock types. RL leaves had lower chlorophyll indices than SC leaves; however, thus salinized RL had the lowest leaf chlorophyll values.

Tissue sodium compartmentation analysis. $\mathrm{Na}^{+}$distribution at the tissue and cell levels in young roots and leaves was determined by CoroNa-Red fluorescence. CoroNa-Red is a water-soluble cell-permeant indicator, which fluoresces only after binding to $\mathrm{Na}^{+}$. In nonsalinized control roots of both tissue types, $\mathrm{Na}^{+}$-induced fluorescence was observed primarily in cortical cells scattered throughout (Figs. 3A and 3C). SC roots accumulated higher levels of $\mathrm{Na}^{+}$than those of RL. The small but noticeable fluorescence signal in the absence of added $\mathrm{Na}^{+}$in Figures $3 \mathrm{~A}$ and $3 \mathrm{C}$ likely resulted from the inherent presence of $\mathrm{Na}^{+}$in irrigation water, soils, and roots. In the salinized treatment, however, a larger number of $\mathrm{Na}^{+}$accumulating cells was observed in roots of SC compared with RL roots (Figs. 3B and 3D). The higher levels of $\mathrm{Na}^{+}$accumulation in SC roots were consistent throughout all samples collected and through the length of the root tips (Fig. 4). In some instances, parenchyma cells within the stele also fluoresced indicating their high $\mathrm{Na}^{+}$ content (arrowhead in Fig. 3B).

Contrary to roots, compartmentation analysis of $\mathrm{Na}^{+}$distribution in leaves from salinized trees demonstrated that RL accumulated considerably larger amounts of $\mathrm{Na}^{+}$in mesophyll parenchyma cells than those of SC (Fig. 5). The large difference in $\mathrm{Na}^{+}$accumulation was consistent in both lamina tissue as well as in the petiole, where accumulation occurred both in cortical cells as well as in pith parenchyma (Figs. 5B and 5D).

Intracellular sodium compartmentation analysis. Fluorescent micrographs (Fig. 6A) and three-dimensional reconstruction analysis of root cortical cells (Fig. 6B-C) confirmed the vacuole as the main storage compartment for cellular $\mathrm{Na}^{+}$. Figure $6 \mathrm{~B}$ shows the three-dimensional topographic outline of several vacuoles of root cells where concave areas represent the location of organelles and cytosolic areas. A prominent feature of all cells was their fluorescent walls and the presence of a brighter cytosolic zone (arrow in Fig. 6B-C) indicating an area where $\mathrm{Na}^{+}$concentration is considerably higher than in the central vacuole. The higher fluorescence intensity of this zone also was apparent in the topographic three-dimensional analysis in Figure 6C. 
Further observations of the brightly fluorescent structure were carried out using CoroNa-Green with its higher fluorescence intensity compared with CoroNa-Red. To avoid possible interference with the cell walls, protoplasts were generated after tissue incubation in $\mathrm{Na}^{+}$. At higher magnification, two types of protoplasts were observed. A set of

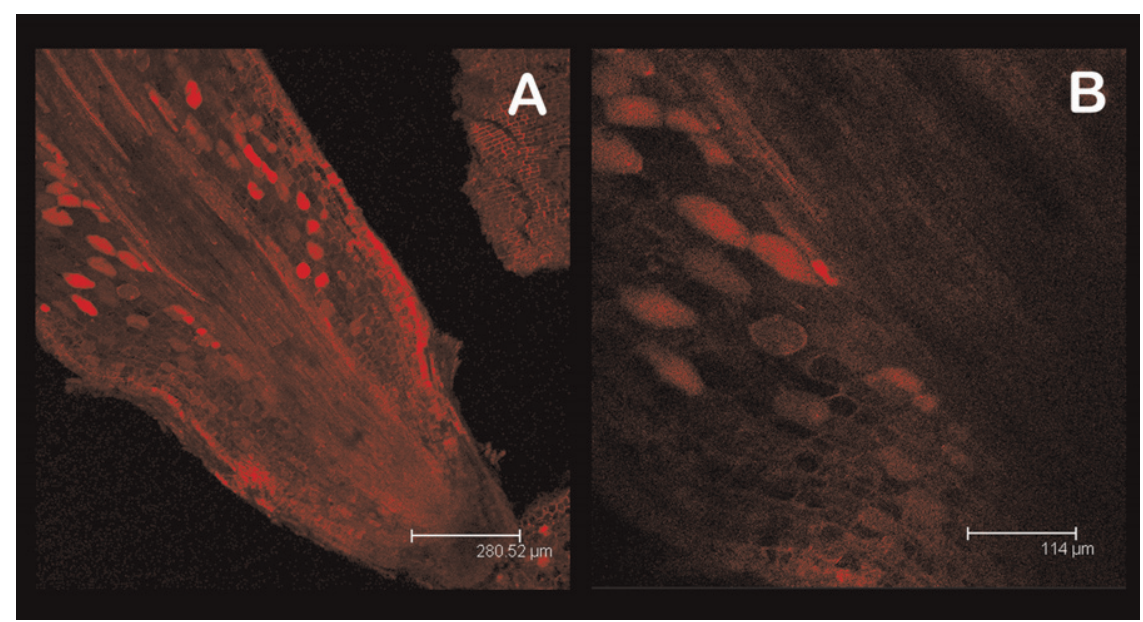

Fig. 4. Laser scanning confocal images of Swingle citrumelo (SC) roots after $50 \mathrm{~mm} \mathrm{NaCl}$ treatment for $42 \mathrm{~d}$. Roots were cut longitudinally incubated in CoroNa-Red before observation (A). B is a close-up showing the cortical nature of the accumulating cells.
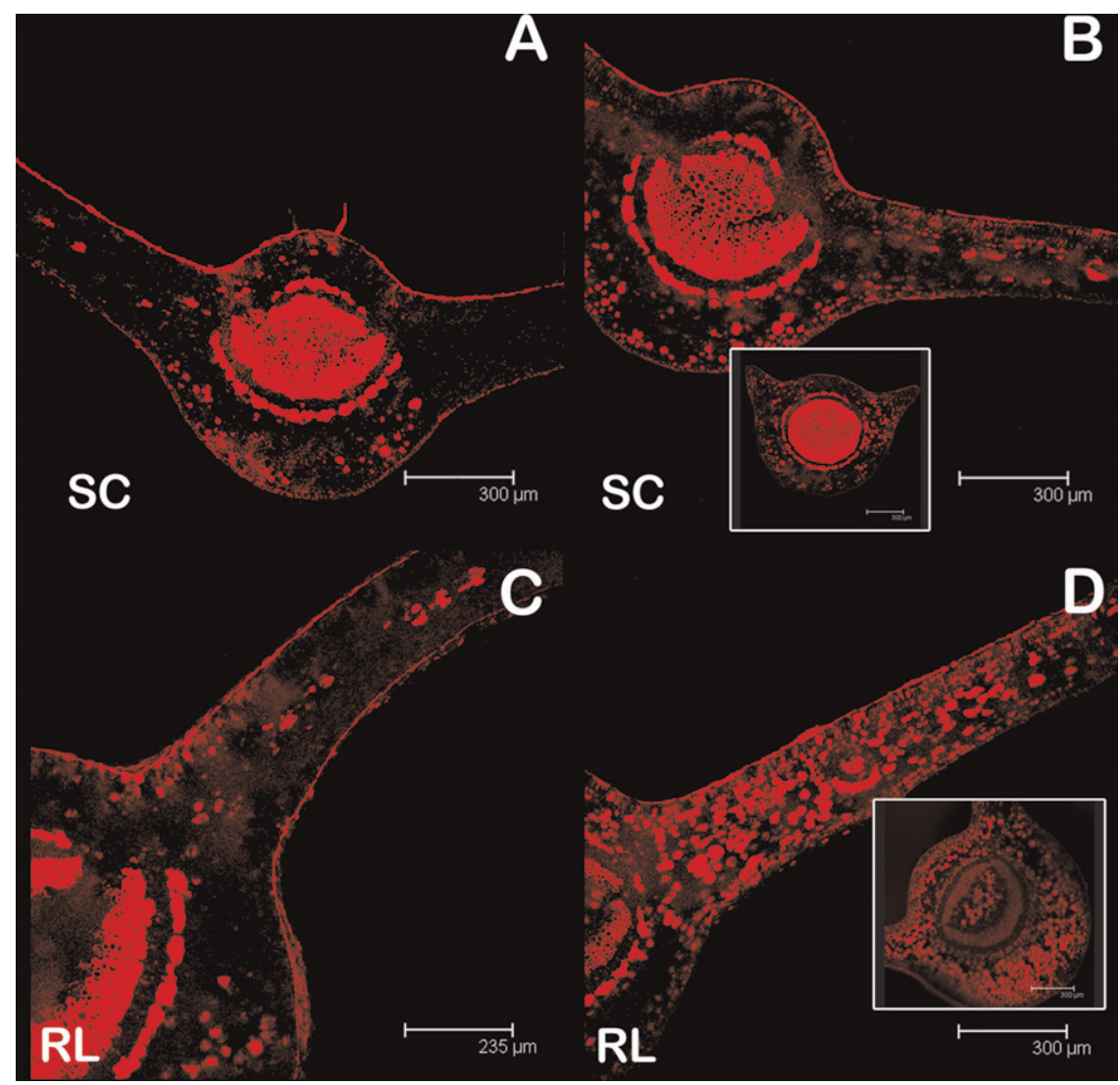

Fig. 5. Laser scanning confocal images of leaves from Swingle citrumelo (SC) and rough lemon (RL) without $\mathrm{NaCl}$ treatment $(\mathbf{A}, \mathbf{C})$ and after $50 \mathrm{~mm} \mathrm{NaCl}$ treatment $(\mathbf{B}, \mathbf{D})$ for $42 \mathrm{~d}$. Leaf segments were cut transversely and labeled with CoroNa-Red before visualization. higher $\mathrm{Na}$ concentration, is very likely that the vacuole, with its much larger size, was capable of storing large amounts of $\mathrm{Na}^{+}$. Fluorescent micrographs using both CoroNaGreen and Hoechst 33342, a nucleic acidspecific stain (Fig. 8), demonstrated that this bright structure did not represent the nucleus. The clear separation of blue and green fluorescence areas indicates that these two structures represent separate entities corresponding to the nucleus (blue) and to an unidentified high $\mathrm{Na}^{+}$-containing compartment of $\approx 2$ to $6 \mu \mathrm{m}$ in diameter.

Confocal images of salinized root segments washed with $1 \mathrm{M} \mathrm{KCl}$ for $2 \mathrm{~h}$ revealed the unexpected persistence of $\mathrm{Na}^{+}$in the cell wall space (Fig. 9). Control tissue incubated in the absence of CoroNa-Red displayed no autofluorescence (Fig. 9A-B). When salinized tissue was washed in incubation media for $2 \mathrm{~h}$ and then incubated in CoroNa-Red, intense fluorescence remained throughout (Fig. 9C-D). However, when salinized root segments were washed with $1 \mathrm{M} \mathrm{KCl}$ for $2 \mathrm{~h}$ before incubation with CoroNa-Red, fluorescence remained only within the stele. Very little fluorescence, if any, persisted in the cortical wall spaces, although some fluorescence remained along the epidermis (arrowhead in Fig. 9F) and casparian band (arrow in Fig. 9F).

\section{Discussion}

Plant growth and leaf ion concentration (Figs. 1 and 2; Table 1) confirmed the previously described relatively high $\mathrm{Cl}^{-}$sensitivity of RL and SC (Levy and Syvertsen, 2004). In addition, concentrations of $\mathrm{Na}^{+}$in salinized RL leaves were four times greater than in SC leaves supporting previously described rootstock difference in $\mathrm{Na}^{+}$accumulation. $\mathrm{Na}^{+}$sequestration in root organs has been reported in a variety of salt-tolerant species (Apse and Blumwald, 2007; Blumwald et al., 2000; Cuin et al., 2011; Møller et al., 2009) and also in citrus rootstocks differing in salt tolerance (Garcia-Sanchez and Syvertsen, 2006). Although the ability to sequester $\mathrm{Na}^{+}$ions in roots, thereby preventing toxic levels of $\mathrm{Na}^{+}$from reaching leaf tissues, has been previously reported in citrus, this is the first report describing cellular and tissue distribution of $\mathrm{Na}^{+}$together in root and leaf tissues of citrus rootstocks differing in their $\mathrm{Na}^{+}$tolerance

Sequestration of $\mathrm{Na}^{+}$away from the cytosol of photosynthetic cells was accomplished in a variety of ways both at the tissue and cell structural levels. Although both citrus varieties appeared to have similar compartmentation strategies at the cell level, our data demonstrated that retention of $\mathrm{Na}^{+}$in the roots provided better protection against $\mathrm{Na}^{+}$ toxicity than cell compartmentation in leaves (Figs. 3 and 5). This conclusion is based on two pieces of evidence. First, tissue $\mathrm{Na}^{+}$ analysis showed a 2-fold higher $\mathrm{Na}^{+}$concentration in salinized roots of $\mathrm{Na}^{+}$-tolerant $\mathrm{SC}$ than in RL (Fig. 2). Second, fluorescence analysis of $\mathrm{Na}^{+}$localization within the tissue 


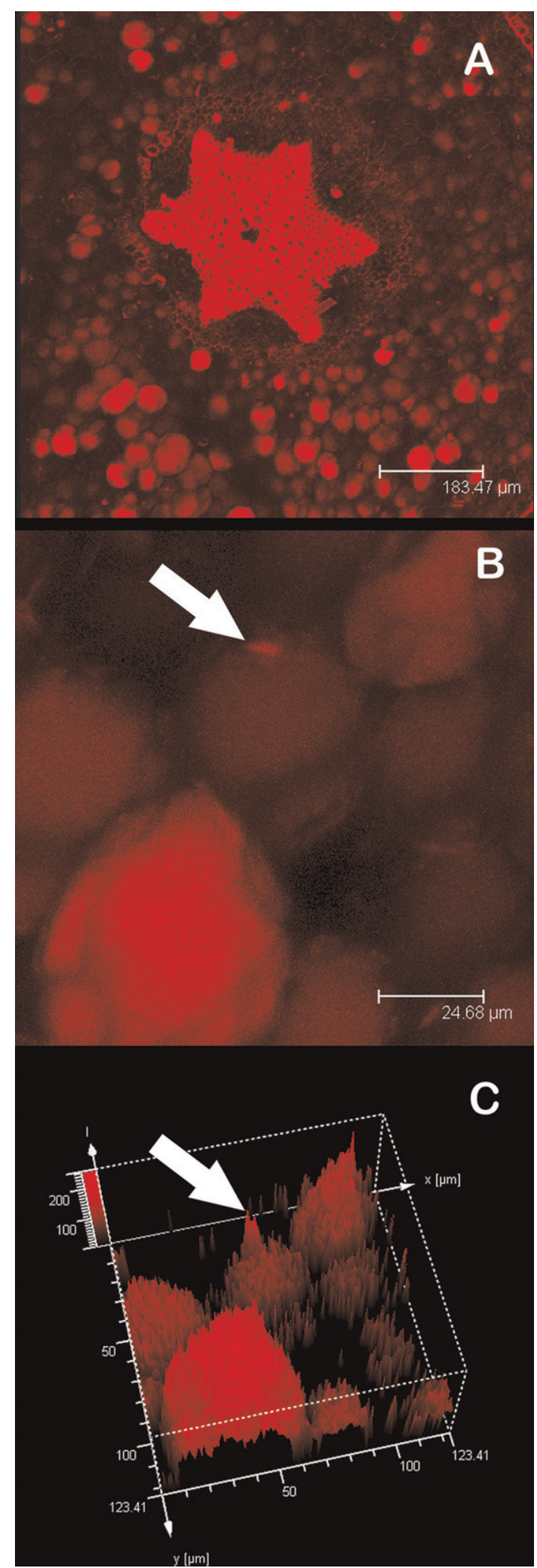

Fig. 6. Three-dimensional images (A-B) of Swingle citrumelo (SC) roots supplied with $50 \mathrm{~mm} \mathrm{NaCl}$ for 42 d. (A) $\mathrm{Na}^{+}$accumulation is evident in cortical cells and in cells inside the pericycle. (B) Three-dimensional image of vacuoles within the cortical region. Arrow points to the highly fluorescent structure commonly observed. (C) Topographic three-dimensional analysis of $\mathbf{B}$ showing the intensely fluorescent sodium $(\mathrm{Na})$-accumulating structures (arrows) peripheral to the larger vacuole.

indicated higher fluorescence in SC root cortical cells than in RL roots (Fig. 3). In addition, fluorescence-based visualization of cellular $\mathrm{Na}^{+}$distribution corresponded to tissue $\mathrm{Na}^{+}$concentration expressed on a dry weight basis.
Retention of $\mathrm{Na}^{+}$within the roots has been proposed as a key mechanism providing $\mathrm{Na}^{+}$ tolerance to glycophytes (Conn and Gilliham, 2010). Our observations support that idea in that the epidermal and cortical cells accumulated symplastic $\mathrm{Na}^{+}$before reaching the vasculature. In citrus, however, $\mathrm{Na}^{+}$was predominantly accumulated in root cortical cells unlike Arabidopsis wild-type (Oh et al., 2009), where substantial $\mathrm{Na}^{+}$was retained by epidermal cells. The pericycle also accumulated $\mathrm{Na}^{+}$in $\mathrm{SC}$ roots (Fig. 3B). This may be a critical mechanism in the relatively high $\mathrm{Na}^{+}$tolerance in $\mathrm{SC}$ because the pericycle remains the last metabolic barrier before solutes enter the xylem stream to move toward leaves (Conn and Gilliham, 2010).

Within leaves, there appeared to be no discriminatory compartmentation between cell types because $\mathrm{Na}^{+}$appeared to be accumulated in photosynthetic cells as well as in parenchyma cells (Fig. 5). Thus, the difference between the $\mathrm{Na}^{+}$accumulation in $\mathrm{SC}$ and RL could be attributed to the greater amount of $\mathrm{Na}^{+}$that bypassed the roots and was allowed to reach the leaves in RL.

Fluorescent scanning micrographs (Figs. 3 to 7) verified the vacuole as the largest $\mathrm{Na}^{+}$ depository in both root and leaf tissues where the vacuole displayed its higher $\mathrm{Na}^{+}$content compared with the cytosol. As a storage compartment, the vacuolar membrane contains a variety of $\mathrm{Na}^{+}$-related transporters capable of removing toxic levels of $\mathrm{Na}^{+}$from the cytosol. Aside from $\mathrm{Na}^{+}$channels, the vacuole contains a $\mathrm{Na}^{+} / \mathrm{H}^{+}$antiporter (Apse and Blumwald, 2007). The relevance of this tonoplast-bound $\mathrm{Na}^{+}$transporter to salt tolerance has been thoroughly demonstrated in several species such as tomato (Zhang and Blumwald, 2001), Arabidopsis (Shi et al., 2003), sugarbeet (Liu et al., 2008), and cotton (He et al., 2005), where increasing expression of the $\mathrm{Na}^{+} / \mathrm{H}^{+}$antiporter resulted in increased salt tolerance. It is noteworthy that not all citrus cells in a given tissue exhibited similar fluorescence intensity, and in some instances, there was no visible fluorescence. This is not uncommon because cryo-scanning electron microscopy (Läuchli et al., 2008; Møller et al., 2009) and radiographic microanalysis (Flowers and Hajibagheri, 2001) of root cells from different species demonstrated that adjacent cells can have different vacuolar $\mathrm{Na}^{+}$ concentrations.

Apart from the vacuole, most cells also contained organelle-like, $2-$ to $6-\mu \mathrm{m}$ structures (Figs. 6 to 8 ) that exhibited higher fluorescence intensity. We cannot identify the nature of these structures based on our analyses; however, when these structures were viewed through successive $\mathrm{Z}$ planes, it became evident that this was a membranebound cytosolic organelle-like structure. In many cells, this was the only fluorescent structure, and all cells that displayed vacuolar fluorescence also contained this organellelike structure (Fig. 6). It is noteworthy that, although vacuolar sequestration of $\mathrm{Na}^{+}$was minimal in RL roots, most cells displayed this highly fluorescent structure (Fig. 3C-D). 


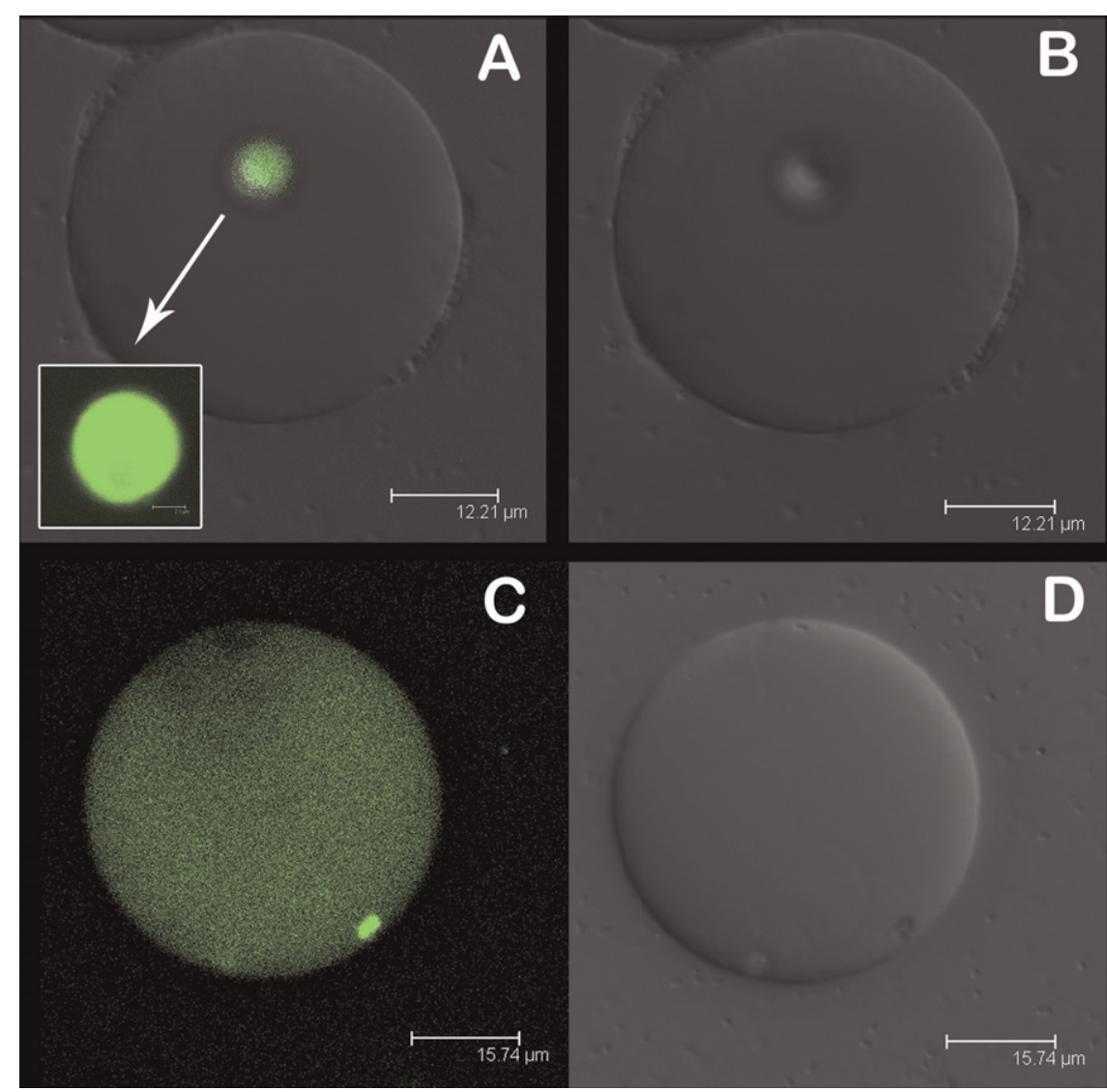

Fig. 7. (A-C) Root protoplast from Swingle citrumelo (SC) grown in $50 \mathrm{~mm} \mathrm{NaCl}$ for $42 \mathrm{~d}$. The figure is a composite of laser scanning confocal microscopy with and without fluorescence. The highly fluorescent cellular structure labeled with CoroNa-Green can be observed against the opaque cell in $\mathbf{A}$, whereas in $\mathbf{C}$, the highly fluorescent structure outshines the $\mathrm{Na}^{+}$-accumulating vacuole.

From these observations, we conclude that $\mathrm{Na}^{+}$was initially sequestered in this type organelle-like structure followed by $\mathrm{Na}^{+}$accumulation in the vacuole. The significance of this structure is uncertain, but it appears that $\mathrm{Na}^{+}$could be stored in two intracellular compartments. Similar observations of a highly intense $\mathrm{Na}^{+}$-containing organelle in Arabidopsis cortical cells at the root tip were made by Hamaji et al. (2009). Although speculative at this point, it is likely that this membrane-bound structure represents an intermediate stage or a delivery point for $\mathrm{Na}^{+}$in the process of endocytosis as in Arabidopsis root cells (Oh et al., 2009). This process has been suggested to be involved in ion uptake into plant cells (MacRobbie, 1971). It is also possible that these small vesicles accumulate $\mathrm{Na}^{+}$and then merge with the main vacuole as observed in yeast cells (Nass and Rao, 1998).

It is generally assumed that once ions pass the endodermis in roots, ions move unrestricted following the movement of water to the xylem vessels (Peng et al., 2004). Extrusion of excess $\mathrm{Na}^{+}$from the cytosol of parenchyma cells by plasma membrane-bound $\mathrm{Na}^{+}$antiporters (Shi et al., 2000) within the epidermis and stele would be impractical if a trapping system were not present to prevent $\mathrm{Na}^{+}$from entering the adjacent xylem vessels. A prominent feature in our fluorescent micrographs of all tissues incubated in CoroNa-Red was the intense fluorescence of the cell walls, especially in the thick-walled xylem and proto-xylem elements (Figs. 3 to 6 and 9). The intense fluorescence was evident in roots from both non-salinized control and $\mathrm{NaCl}$-treated plants and was not the result of autofluorescence because roots incubated without CoroNa-Red lacked the fluorescent red signal (Fig. 9A-B). The apoplast is generally considered as a cation-binding matrix because it contains many disassociated carboxyl residues found in the pectic portion of the cell walls (Plett and Møller, 2010). Because the 2-h $\mathrm{K}^{+}$wash only removed $\mathrm{Na}^{+}$ from cortical cell walls but not from the stele (Fig. 9E-F), it is reasonable to assume that the cell walls of the xylem and surrounding stele tissue are capable of retaining $\mathrm{Na}^{+}$providing an additional $\mathrm{Na}^{+}$retention barrier. $\mathrm{Na}^{+}$adsorption by root cell walls has been previously demonstrated in barley roots (Stassart et al., 1981) and for metals in a wide range of plants (Mari and Lebrun, 2006). It is therefore possible that the cell walls of the stele could provide an auxiliary structural trapping process, regardless of the cellular compartmentation capabilities.

Our results support our original hypothesis that $\mathrm{Na}^{+}$sequestration in the root vacuoles

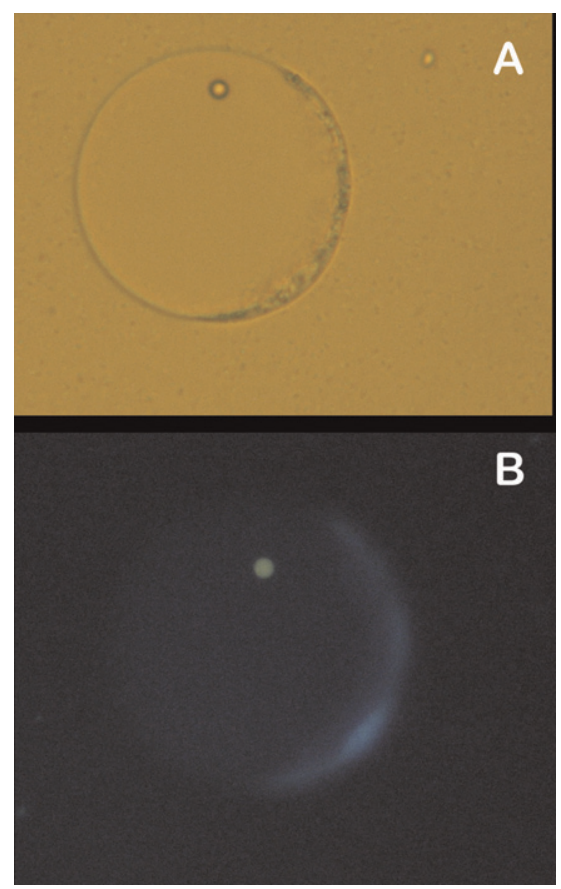

Fig. 8. (A) Light micrograph image of a protoplast from Swingle citrumelo (SC) roots grown in $50 \mathrm{~mm} \mathrm{NaCl}$ and incubated in Hoechst 33342 and CoroNa-Green before observation. (B) Fluorescent micrograph of $\mathbf{A}$.

of the relatively $\mathrm{Na}^{+}$-tolerant $\mathrm{SC}$ would be greater than in RL roots. Vacuolar sequestration, therefore, is a significant contributing mechanism to the ability of SC roots to maintain lower levels of $\mathrm{Na}^{+}$in leaves compared with leaves associated with RL roots. This adds to our understanding of mechanisms of salinity tolerance in contrasting citrus rootstocks. Distribution of fluorescence in SC root protoplasts verified vacuolar localization of $\mathrm{Na}^{+}$and tissue concentrations expressed on a dry weight basis.

\section{Literature Cited}

Apse, M.P. and E. Blumwald. 2007. $\mathrm{Na}^{+}$transport in plants. FEBS Lett. 581:2247-2254.

Blumwald, E., G.S. Aharon, and M.P. Apse. 2000. Sodium transport in plant cells. Biochim. Biophys. Acta 1465:140-151.

Castle, W.S., K. Bowman, J.H. Graham, and D.P.H. Tucker. 2006. Florida citrus rootstock selection guide. UF/IFAS, SP-248. Univ. FL Ext. Serv., Gainesville, FL.

Castle, W.S., D.P.H. Tucker, A.H. Krezdorn, and C.O. Youtsey. 1993. Rootstocks for Florida citrus. 2nd Ed. UF/IFAS SP-42. Univ. FL Ext. Serv., Gainesville, FL.

Conn, S. and M. Gilliham. 2010. Comparative physiology of elemental distributions in plants. Ann. Bot. (Lond.) 105:1081-1102.

Cuin, T.A., J. Bose, G. Stefano, D. Jha, M. Tester, S. Mancuso, and S. Shabala. 2011. Assessing the role of root plasma membrane and tonoplast $\mathrm{Na}^{+} / \mathrm{H}^{+}$exchangers in salinity tolerance in wheat: In planta quantification methods. Plant Cell Environ. 34:947-961.

Davenport, R.J. and M. Tester. 2000. A weakly voltage-dependent, nonselective cation channel mediates toxic sodium influx in wheat. Plant Physiol. 122:823-834. 


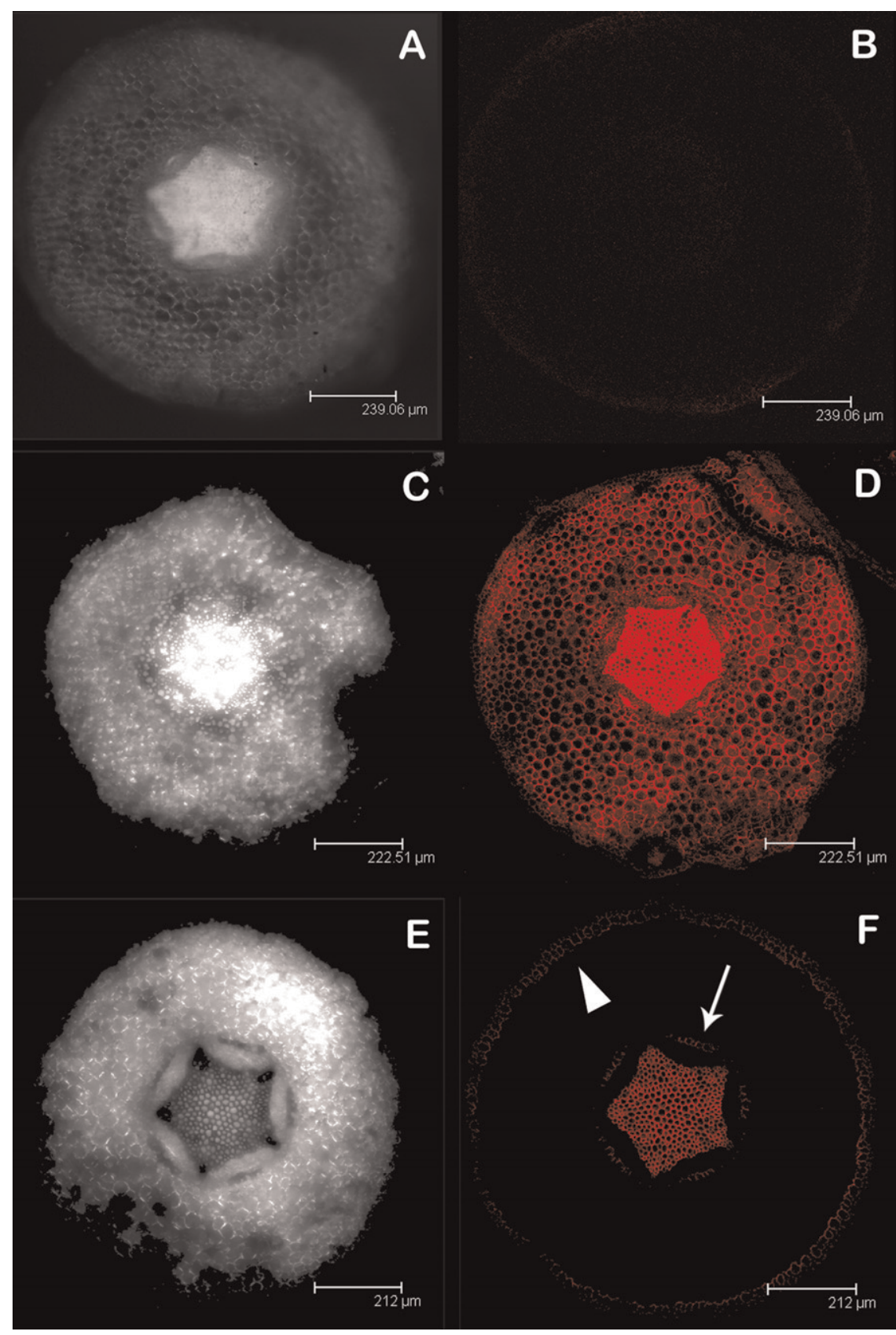

Fig. 9. Light micrographs and laser scanning confocal images of roots segments from Swingle citrumelo (SC) treated with $50 \mathrm{~mm} \mathrm{NaCl}$ for $42 \mathrm{~d}$. (A) Light micrograph of control roots without added CoroNaRed sodium indicator. (B) Laser scanning confocal image of A. (C) Light micrograph of control roots incubated in CoroNa-Red and washed with a $10 \mathrm{~mm}$ buffer solution. (D) Laser fluorescent scanning confocal image of C. (E) Light micrograph of control roots incubated in CoroNa-Red and washed with a $1 \mathrm{M} \mathrm{KCl}$ for $2 \mathrm{~h}$. (F) Laser scanning confocal image of $\mathbf{E}$. (Arrow indicates the casparian strip, whereas the triangular arrowhead denotes the epidermis.)

Flowers, T.J. and M.A. Hajibagheri. 2001. Salinity tolerance in Hordeum vulgare: Ion concentrations in root cells of cultivars differing in salt tolerance. Plant Soil 231:1-9.

Garcia-Sanchez, F.G. and J.P. Syvertsen. 2006. Salinity tolerance of Cleopatra mandarin and Carrizo citrange citrus rootstock seedling is affected by $\mathrm{CO}_{2}$ enrichment during growth. J. Amer. Soc. Hort. Sci. 131:24-31.

Garcia-Sanchez, F.G. and J.P. Syvertsen. 2009. Substrate type and salinity affect growth allocation, tissue ion concentrations and physiological responses of Carrizo citrange seedlings. HortScience 44:1432-1437. of an Arabidopsis vacuolar sodium/proton antiporter gene in cotton improves photosynthetic performance under salt conditions and increases fiber yield in the field. Plant Cell Physiol. 46:1848-1854.

Läuchli, A., R.A. James, C.X. Huang, M. McCully, and R. Munns. 2008. Cell-specific localization of $\mathrm{Na}^{+}$in roots of durum wheat and possible control points for salt exclusion. Plant Cell Environ. 31:1565-1574.

Levy, Y. and J.P. Syvertsen. 2004. Irrigation water quality and salinity effects in citrus trees. Hort. Rev. 30:37-82.

Liu, H., Q. Wang, M. Yu, Y. Zhang, Y. Wu, and H. Zhang. 2008. Transgenic salt-tolerant sugar beet (Beta vulgaris L.) constitutively expressing an Arabidopsis thaliana vacuolar $\mathrm{Na}^{+} / \mathrm{H}^{+}$antiporter gene, AtNHX3, accumulates more soluble sugar but less salt in storage roots. Plant Cell Environ. 31:1325-1334.

Maas, E.V. 1993. Salinity and citriculture. Tree Physiol. 12:195-216.

MacRobbie, E.A.C. 1971. Fluxes and compartmentation in plant cells. Annu. Rev. Plant Physiol 22:75-96.

Mari, S. and M. Lebrun. 2006. Metal immobilization: Where and how? Topics Cur. Gene 14:273-298

Møller, I.S., M. Gilliham, D. Jha, G.M. Mayo, S.J. Roy, J.C. Coates, J. Haseloff, and M. Tester. 2009. Shoot $\mathrm{Na}^{+}$exclusion and increased salinity tolerance engineered by cell type-specific alteration of $\mathrm{Na}^{+}$transport in Arabidopsis. Plant Cell 21:2163-2178.

Munns, R. and M. Tester. 2008. Mechanisms of salinity tolerance. Annu. Rev. Plant Biol. 59: 651-681.

Nass, R. and R. Rao. 1998. Novel localization of a $\mathrm{Na}^{+} / \mathrm{H}^{+}$exchanger in a late endosomal compartment of yeast. J. Biol. Chem. 273: 21054-21060

Obreza, T.A. and K.T. Morgan. 2008. Nutrition of Florida citrus trees. UF/IFAS SL 253. Univ. FL, Gainesville, FL.

Oh, D.-H., E. Leidi, Q. Zhang, S.-M. Hwang, Y. Li, F.J. Quintero, X. Jiang, M.P. D' Urzo, S.Y. Lee, Y. Zhao, J.D. Bahk, R.A. Bressan, D.-J. Yun, J.M. Pardo, and H.J. Bohnert. 2009. Loss of halophytism by interference with SOS1 expression. Plant Physiol. 151:210-222.

Peng, Y.H., Y.F. Zhu, Y.Q. Mao, S.M. Wang, W.A. $\mathrm{Su}$, and Z.C. Tang. 2004. Alkali grass resists salt stress through high $\left[\mathrm{K}^{+}\right]$and endodermis barrier to $\mathrm{Na}^{+}$. J. Expt. Bot. 55:939-949.

Plett, D.C. and I.S. Møller. 2010. $\mathrm{Na}^{+}$transport in glycophytic plants: What we know and would like to know. Plant Cell Environ. 33:612-626.

Redjala, T., T. Sterckeman, S. Skiker, and G. Echevarria. 2010. Contribution of apoplast and symplast to short-term nickel uptake by maize and Leptoplax emarginata roots. Environ. Exp. Bot. 68:99-106

Shi, H., M. Ishitani, C. Kim, and J.K. Zhu. 2000 The Arabidopsis thaliana salt tolerance gene SOS1 encodes a putative $\mathrm{Na}^{+} / \mathrm{H}^{+}$antiporter. Proc. Natl. Acad. Sci. USA 97:6896-6901.

Shi, H., B.H. Lee, S.J. Wu, and J.K. Zhu. 2003 Overexpression of a plasma membrane $\mathrm{Na}^{+} / \mathrm{H}^{+}$ antiporter gene improves salt tolerance in Arabidopsis thaliana. Nat. Biotechnol. 21:8185 .

Shi, H., F.J. Quintero, J.M. Pardo, and J.K. Zhu. 2002. The putative plasma membrane $\mathrm{Na}^{+} / \mathrm{H}^{+}$ antiporter SOS1 controls long-distance $\mathrm{Na}^{+}$ transport in plants. Plant Cell 14:465-477.

Stassart, J.M., L. Neirinckx, and R. Dejaegree. 1981. The interactions between monovalent cations and calcium during their adsorption 
on isolated cell walls and absorption by intact barley roots. Ann. Bot. (Lond.) 47:647-652.

Syvertsen, J.P., J.C. Melgar, and F. GarciaSanchez. 2010. Salinity tolerance and leaf water use efficiency in citrus. J. Amer. Soc. Hort. Sci. 135:33-39.

Tester, M. and R. Davenport. 2003. $\mathrm{Na}^{+}$tolerance and $\mathrm{Na}^{+}$transport in higher plants. Ann. Bot. (Lond.) 91:503-527.
Zhang, H.-X. and E. Blumwald. 2001. Transgenic salt-tolerant tomato plants accumulate salt in foliage but not in fruit. Nature Biotechnol. 19:765-768.

Zhang, H.-X., J.N. Hodson, J.P. Williams, and E. Blumwald. 2001. Engineering salt-tolerant Brassica plants: Characterization of yield and seed oil quality in transgenic plants with increased vacuolar sodium accumulation.
Proc. Natl. Acad. Sci. USA 98:1283212836.

Zhu, J.-K. 2000. Genetic analysis of plant salt tolerance using Arabidopsis. Plant Physiol. 124: 941-948.

Zekri, M. and L.R. Parsons. 1992. Salinity tolerance of citrus rootstocks: Effects of salt on root and leaf mineral concentrations. Plant Soil 147:171-181. 